\title{
Variability Studies in Brinjal (Solanum melongena L.)
}

\author{
B. M. Shilpa*, R. M. Dheware and R. B. Kolekar
}

Dept. of Horticulture, College of Agriculture, Latur Vasantrao Naik Marathwada Krishi Vidyapeeth, Parbhani, Maharashtra (431 402), India

\section{Corresponding Author}

B. M. Shilpa

e-mail: rupalikolekar4@gmail.com

\author{
Article History \\ Article ID: AR1865d \\ Received in $16^{\text {th }}$ March, 2018 \\ Received in revised form $28^{\text {th }}$ September, 2018 \\ Accepted in final form $30^{\text {th }}$ September, 2018
}

\begin{abstract}
The present investigation was carried out at Instructional-Cum-Research Farm, Department of Horticulture, College of Agriculture, Latur during kharif season, 2016-17; to study the variabilities in brinjal. To conduct the study eighteen genotypesof brinjal viz., Poiyoor, Nagarkoil, Chettipulam, Vengaloor, Br.CVK (spineless), Erangere, Rampur Local, Panrutti, Rayadurga local, Gulabi, Pusa Purple round, Arka Keshav, Malapura Local, Pune Kateri, Padhukottai, Kateri Wangi, Br. CVK (spine) and Vettai Mangalam wereevaluated for 19 quantitative characters. A wide range of variations were observed among different genotypes for all growth, yield and quality characters. The phenotypic coefficient of variation was higher than genotypic coefficient of variation for all the traits. High (>20\%) genotypic coefficient of variation (GCV) and phenotypic coefficient variation (PCV) were observed for fruit dry matter \%, fruit yield plant ${ }^{-1}$, weight of fruits, leaf petiole length, fruit yield hectare $^{-1}$, fruit yield plot ${ }^{-1}$, plant height and days required for first flowering. High heritability (>60\%) coupled with high genetic advance as percent over mean (>20\%) were recorded for the characters viz., plant height, leaf petiole length, days required for first flowering, fruit pedicel length, fruit length, fruit diameter, number of fruits plant ${ }^{-1}$, weight of fruits, fruit yield plant ${ }^{-1}$, fruit yield plot ${ }^{-1}$, fruit yield hectare ${ }^{-1}$, fruit dry matter $\%$ and fruit protein $\%$. The additive component is predominant for the above characters.
\end{abstract}

Keywords: Genotype, variability, brinjal, Solanum melongena L.

\section{Introduction}

Brinjal (Solanum melongena L.) is one of the most popular and widely cultivated native vegetable crops of India. The crop is extremely variable in India, substantiated by the presence of wild relatives of Solanum melongena which are perennial herb or shrub with bitter fruits (Bhaduri, 1951). Solanum is a very large and important genus comprising between 1000 to 1400 described species of which at least 150 are tuberous, rest being non-tuberous (Daunay and Lester, 1988). It is known as poor man's vegetable and also called as eggplant. Eggplant is also a rich source of magnesium, calcium and iron (Kowalski et al., 2003). Germplasm collection, maintenance and its evaluation for economically important traits is a prerequisite for starting any breeding programme for the genetic improvement of the crop.

It is an important crop in the warm areas of world and being grown extensively in India, Bangladesh, Pakistan, China and Philippines. It is also popular in Egypt, France, Italy and United States of America (Vishnuswaroop, 2012). The success of any crop improvement programme largely depends upon the nature and magnitude of the genetic variability existing in breeding material with which plant breeder is working (Prabhu et al., 2009). The phenotypic expression of the plant character is mainly controlled by the genetic makeup of the plant and the environment, in which it is grown and the interaction between the genotypes and environment. Partitioning of total correlation into direct and indirect effects would be worthwhile for an effective selection program (Kalloo, 1994). Keeping all these points in view an investigation was carried out to access the nature and extent of genetic variability for quantitative traits.

\section{Materials and Methods}

The present investigation was carried out at InstructionalCum-Research Farm, Department of Horticulture, College of Agriculture, Latur during kharif season, 2016-17. To study the variability studies in brinjal (Solanum melongena L.), spaced at $60 \times 45 \mathrm{~cm}^{2}$ with 36 plots. The statistical design was adapted RBD with two replications. The experimental material comprised of 18 genotypes viz., Poiyoor, Nagarkoil, Chettipulam, Vengaloor, Br.CVK (Spineless), Erangere, Rampur Local, Panrutti, Rayadurga Local, Gulabi, Pusa Purple Round, ArkaKeshav, Malapur Local, Pune Kateri, Padhukottai, Kateri Wangi, Br. CVK (Spinyness) and Vettai Mangalam. Genotypic and phenotypic coefficients of variance were estimated 
according to Burton and Devane (1953), PCV and GCV were classified (Subramanian and Memon, 1973), The broad sense heritability $\left(h^{2}\right)$ was estimated by Weber and Moorthy (1952), Genetic advance for each character was predicted by Johnson et al. (1955) and Path coefficient analysis suggested by Wright (1921) and Dewey and Lu (1959). The field traits were carried out the method suggested by Panse and Sukhatme (1985).

\section{Results and Discussion}

The analysis of variance for eighteen characters are given in Table 1 . The analysis of variance indicated significantly higher amount of variability among the genotypes for all the characters studied, except for days required to physiological maturity found non-significant. This indicates that, high

\begin{tabular}{|c|c|c|c|c|c|c|}
\hline SI. No. & Source of variation/character & Replication & $\begin{array}{l}\text { Treatments } \\
\text { (Genotypes) }\end{array}$ & Error & SEm \pm & $\mathrm{CD}(p=0.05)$ \\
\hline 1. & Plant height (cm) & 3.62 & $466.06^{* *}$ & 44.84 & 4.735 & 14.014 \\
\hline 2. & Plant spread $(\mathrm{cm})^{2}$ & 55637 & $98110^{* *}$ & 32057 & 126.6 & 374.68 \\
\hline 3. & No. of primary branches plant ${ }^{-1}$ & 0.22 & $0.41^{* *}$ & 0.06 & 0.173 & 0.513 \\
\hline 4. & Leaf petiole length $(\mathrm{mm})$ & 1.59 & $83.6^{* *}$ & 1.29 & 0.803 & 2.376 \\
\hline 5. & No. of days required for first flowering & 8.03 & $84.3^{* *}$ & 4.03 & 1.419 & 4.200 \\
\hline 6. & No. of hermaphrodite flowers inflorescence ${ }^{-1}$ & 0.32 & $0.5^{* *}$ & 0.07 & 0.192 & 0.569 \\
\hline 7. & Fruit pedicel length $(\mathrm{mm})$ & 25.07 & $90.35^{* *}$ & 5.75 & 1.695 & 5.017 \\
\hline 8. & Fruit pedicel thickness (mm) & 1.21 & $1.3^{* *}$ & 0.5 & 0.500 & 1.481 \\
\hline 9. & Fruit length $(\mathrm{cm})$ & 0.44 & $7.71^{* *}$ & 0.58 & 0.536 & 1.587 \\
\hline 10. & Days required to physiological maturity & 0.69 & 1.58 & 1.46 & 0.854 & 2.528 \\
\hline 11. & Fruit diameter $(\mathrm{cm})$ & 0.09 & $1.53^{* *}$ & 0.19 & 0.305 & 0.903 \\
\hline 12. & No. of fruits cluster ${ }^{-1}$ & 0.16 & $0.31^{* *}$ & 0.12 & 0.243 & 0.718 \\
\hline 13. & No. of fruits plant ${ }^{-1}$ & 4.77 & $86.78^{* *}$ & 6.42 & 1.792 & 5.304 \\
\hline 14. & Weight of fruits (g) & 64.51 & $757.39^{* *}$ & 78.69 & 6.272 & 18.56 \\
\hline 15. & Fruit yield plant ${ }^{-1}(\mathrm{~kg})$ & 0.03 & $0.24^{* *}$ & 0.02 & 0.1 & 0.31 \\
\hline 16. & Fruit yield plot ${ }^{-1}(\mathrm{~kg})$ & 13.32 & $19.6^{* *}$ & 3.92 & 1.4 & 4.14 \\
\hline 17. & Fruit yield hectare $^{-1}(\mathrm{q})$ & 2155.56 & $3171.04^{* *}$ & 633.89 & 17.8 & 16.61 \\
\hline 18. & Fruit dry matter (\%) & 5.57 & $948.28^{* *}$ & 7.63 & 1.953 & 5.780 \\
\hline 19. & Fruit protein (\%) & 0.01 & $0.08^{* *}$ & 0 & 0.04 & 0.12 \\
\hline
\end{tabular}

${ }^{* *}$ Significant at $(p=0.01) ;{ }^{*}$ significant at $(p=0.05)$

variability existed for the characters studied and considerable improvement could be achieved in most of the characters by selection. However, the analysis of variance by itself is not enough and conclusive to explain all the inherent genotypic variance in the genotypes.

\subsection{Genotypic and phenotypic coefficient of variation}

In the present investigation high GCV and PCV were observed for plant height, leaf petiole length, days required for first flowering, weight of fruits, fruit yield plant ${ }^{-1}$, fruit yield plot ${ }^{-1}$, fruit yield hectare ${ }^{-1}$ and fruit dry matter $\%$ are given in Table 2 . These characters recorded higher range of variation and have better scope of improvement through selection. High estimates of GCV and PCV for yield plot $^{-1}$ and yield hectare ${ }^{-1}$ are in accordance with earlier reports of Shekar et al. (2012). High estimates of GCV and PCV for fruit weight is in accordance with the findings of Muniappan et al. (2010). Moderate GCV and PCV were observed for number of hermaphrodite flowers inflorescence ${ }^{-1}$, fruit pedicel length, fruit pedicel thickness, fruit length, number of fruits cluster ${ }^{-1}$, number of fruits plant ${ }^{-1}$ and fruit protein \%.

\subsection{Heritability and genetic advance}

Very often, heritability in broad sense is not the true indicator of inheritance of traits, since only additive component of genetic variance is transferred from generation to generation. Therefore heritability in broad sense may mislead in judging the effectiveness of selection for the trait. Considering heritability in broad sense along with genetic advance over mean may reveal the prevalence of specific components (additive or non-additive) for the trait more accurately.

In the present study, high heritability coupled with high genetic advance as percent over mean was recorded for the characters viz., plant height, leaf petiole length, days 
Table 2: Estimates of components for mean, range, variance, heritability and genetic advance for different characters of brinjal genotypes

\begin{tabular}{|c|c|c|c|c|c|c|c|c|c|c|}
\hline $\begin{array}{l}\text { Sl. } \\
\text { No. }\end{array}$ & $\begin{array}{l}\text { Source of variation/ } \\
\text { character }\end{array}$ & $\begin{array}{l}\text { Grand } \\
\text { mean }\end{array}$ & Range & GV & PV & $\begin{array}{l}\text { GCV } \\
(\%)\end{array}$ & $\begin{array}{l}\text { PCV } \\
(\%)\end{array}$ & $\begin{array}{l}\mathrm{h}^{2} \\
(\%)\end{array}$ & GA & $\begin{array}{c}\text { GAM } \\
(\%)\end{array}$ \\
\hline 1. & Plant height $(\mathrm{cm})$ & 69.69 & 43.41-99.47 & 210.6 & 255.45 & 20.82 & 22.93 & 82.44 & 27.14 & 38.94 \\
\hline 2. & Plant spread $(\mathrm{cm})^{2}$ & 936.56 & $645.21-1571.86$ & 33026.9 & 65083.5 & 19.4 & 27.23 & 50.74 & 266.68 & 28.47 \\
\hline 3. & $\begin{array}{l}\text { No. of primary branches } \\
\text { plant }^{-1}\end{array}$ & 4.31 & $3.50-5.40$ & 0.17 & 0.24 & 9.75 & 11.29 & 74.62 & 0.74 & 17.16 \\
\hline 4. & Leaf petiole length ( $\mathrm{mm}$ ) & 21.80 & $12.78-33.97$ & 41.15 & 42.45 & 29.42 & 29.88 & 96.96 & 13.01 & 59.67 \\
\hline 5. & $\begin{array}{l}\text { No. of days required for } \\
\text { first flowering }\end{array}$ & 30.31 & $20-39$ & 40.13 & 44.17 & 20.9 & 21.92 & 90.88 & 12.44 & 41.04 \\
\hline 6. & $\begin{array}{l}\text { No. of hermaphrodite } \\
\text { flowers inflorescence }{ }^{-1}\end{array}$ & 4.13 & $3.30-5.10$ & 0.21 & 0.29 & 11.12 & 12.93 & 74.01 & 0.81 & 19.61 \\
\hline 7. & Fruit pedicel length (mm) & 43.48 & $34.32-57.16$ & 42.3 & 48.05 & 14.95 & 15.94 & 88.03 & 12.57 & 28.90 \\
\hline 8. & $\begin{array}{l}\text { Fruit pedicel thickness } \\
(\mathrm{mm})\end{array}$ & 6.30 & $4.73-7.64$ & 0.4 & 0.9 & 10.05 & 15.07 & 44.54 & 0.87 & 13.80 \\
\hline 9. & Fruit length (cm) & 10.98 & $8.05-14.50$ & 3.56 & 4.14 & 17.2 & 18.53 & 86.11 & 3.61 & 32.87 \\
\hline 10. & $\begin{array}{l}\text { Days required to } \\
\text { physiological maturity }\end{array}$ & 5.14 & $3.50-7$ & 0.058 & 1.52 & 4.71 & 23.97 & 3.8 & 0.09 & 1.75 \\
\hline 11. & Fruit diameter $(\mathrm{cm})$ & 4.47 & $3.09-6.36$ & 0.67 & 0.86 & 18.37 & 20.75 & 78.35 & 1.49 & 33.33 \\
\hline 12. & No. of fruits cluster ${ }^{-1}$ & 2.67 & $2.20-3.40$ & 0.09 & 0.21 & 11.5 & 17.25 & 44.44 & 0.42 & 15.73 \\
\hline 13. & No. of fruits plant ${ }^{-1}$ & 41.21 & $30.70-54.80$ & 40.17 & 46.6 & 15.37 & 16.56 & 86.21 & 12.12 & 29.41 \\
\hline 14. & Weight of fruits (g) & 58.89 & $41.50-106.2$ & 339.35 & 418.04 & 30.75 & 34.13 & 81.17 & 34.19 & 58.05 \\
\hline 15. & Fruit yield plant ${ }^{-1}(\mathrm{~kg})$ & 0.87 & $0.55-1.66$ & 0.1 & 0.13 & 37.63 & 41.44 & 82.49 & 0.61 & 70.11 \\
\hline 16. & Fruit yield plot ${ }^{-1}(\mathrm{~kg})$ & 11.91 & $8.95-19.95$ & 7.8 & 11.76 & 23.5 & 28.78 & 66.68 & 4.71 & 39.54 \\
\hline 17. & Fruit yield hectare $^{-1}(q)$ & 151.54 & $113.84-253.76$ & 1268.57 & 1902.47 & 23.5 & 28.78 & 66.68 & 59.91 & 39.53 \\
\hline 18. & Fruit dry matter (\%) & 52.83 & $7.43-87.51$ & 470.32 & 477.96 & 41.04 & 41.38 & 98.4 & 44.31 & 83.87 \\
\hline 19. & Fruit protein (\%) & 1.16 & $0.84-1.38$ & 0.04 & 0.04 & 17.27 & 18 & 92.05 & 0.39 & 33.62 \\
\hline
\end{tabular}

GV: Genotypic variance; PV: Phenotypic variance; GCV: Genotypic coefficient of variation; PCV: Phenotypic coefficient of variation, $h^{2}$ : board sense heritability; GA: Genetic advance; GAM: Genetic advance as \% of Mean

required for first flowering, fruit pedicel length, fruit length, fruit diameter, number of fruits plant ${ }^{-1}$, weight of fruits, fruit yield plant ${ }^{-1}$, fruit yield plot ${ }^{-1}$, fruit yield hectare ${ }^{-1}$, fruit dry matter $\%$ and fruit protein $\%$ given in Table 2 . Results for days required for first flowering is in agreement with the findings of Lohakare et al. (2008). High heritability coupled with high GAM for fruit length and fruit diameter is with agreement of Senapati et al. (2009) and Arunkumar et al. (2013). Results obtained for yield plot ${ }^{-1}$ and yield hectare ${ }^{-1}$ are in accordance with findings of Shekar et al. (2012). Results for number of days required for flowering, fruit weight, and number of fruits plant $^{-1}$ are in accordance with findings of Ram et al. (2007). Moderate heritability with moderate GAM was observed for fruit pedicel thickness and number of fruits cluster ${ }^{-1}$.

\section{Conclusion}

The estimates of phenotypic and genotypic variances showed a considerable range of variation for most of the characters. It indicated considerably high amount of variability among the different genotypes under study. The estimates of PCV were greater than the GCV for all the traits which performed role of environment in the expression of the characters.

\section{References}

Arunkumar, B., Kumar, S.V., Prakash, C.G., 2013. Genetic variability and divergence studies in brinjal (Solanum melongena L.). Bioinfolet Journal 10, 739-744.

Bhaduri, P.N., 1951. Inter-relationship of non-tuberiferous species of Solanum with some consideration on the origin of brinjal. Indian Journal of Genetics and Plant Breeding 2, 75-86.

Burton, G.W., Devane, E.M., 1953. Estimating heritability from replicated clonal material. Agronomy Journal 45, 478-481. 
Daunay, M.C., Lester, R.N., 1988. The usefulness of taxonomy for solanaceae breeders with special reference to the genus Solanum and (Solanum melongena L.) Capsicum newsletter 7, 70-79.

Dewry, D.H., Lu, K.H., 1959. A correlation and path analysis of components of crested wheat grass production. Agronomy Journal 51, 515-518.

Johnson, H.W., Robinson, H.F., Comstock, R.S., 1955. Estimation of genetic and environmental variability in soyabean. Agronomy Journal 41, 314-318.

Kalloo, G., 1994. Vegetable breeding. Panima Educational Book Agency, New Delhi, 51.

Kowalski, R., Kowalska, G., Wiercinski, J., 2003. Chemical composition of fruits of three eggplant (Solanum melongena L.) cultivars. Folia Horticulturae 15(2), 89-95.

Lohakare, A.S., Dod, V.N., Peshattiwar, P.D., 2008. Correlation and path analysis studies in green fruited brinjal. Asian Journal of Horticulture 3(1), 173-175.

Muniappan, S., Saravanan K., Ramya, B., 2010. Studies on genetic divergence and variability for certain economic characters in eggplant (Solanum melongena L.) Electronic Journal of Plant Breeding 1(4), 462-465.

Panse, V.S., Sukhatme, P.V., 1985. Statistical Methods for Agricultural Worker. ICAR, New Delhi.

Prabhu, M., Natarajan, S., Pugalendhi, L., 2009. Variability and heritability studies in $\mathrm{F}^{5}$ and $\mathrm{F}^{6}$ progenies of brinjal.
American-Eurasian Journal of Sustainable Agriculture 3(3), 306-309.

Ram, K., Singh, P., Singh, R., 2007. Studies on genetic variability and selection parameters for economic characters in egg plant. International Journal of Plant Sciences 2(1), 99-102.

Senapati, N., Mishra, H.N., Bhoi, M.K., Dash, S.K., Prasad, G., 2009. Genetic variability and divergence studies in brinjal (Solanum melongena L.). Journal of Vegetation Science, 36(2), 150-154.

Shekar, C.K., Ashok, P., Sasikala, K., 2012. Studies on heritability and multivariate analyses in brinjal (Solanum melongena L.).Vegetable Crops Research Bulletin 76(1), 79-88.

Subramaniyan, S., Memon, M., 1973. Heterosis and inbreeding depression in rice. Madras Agriculture Journal 60, 1139.

Vishnuswaroop, 2012. Vegetable Science and Technology in India. Kalyani Publishers, India, 318.

Weber, C.R., Moorthy, H.R., 1952. Heritable and non-heritable relationship and variability of oil content and agronomic characters in the $\mathrm{F}^{2}$ generation of soybean crosses. Agronomy Journal 44, 202-209.

Wright, S., 1921. Correlation and causation. Journal Agriculture Research 20, 557-558. 